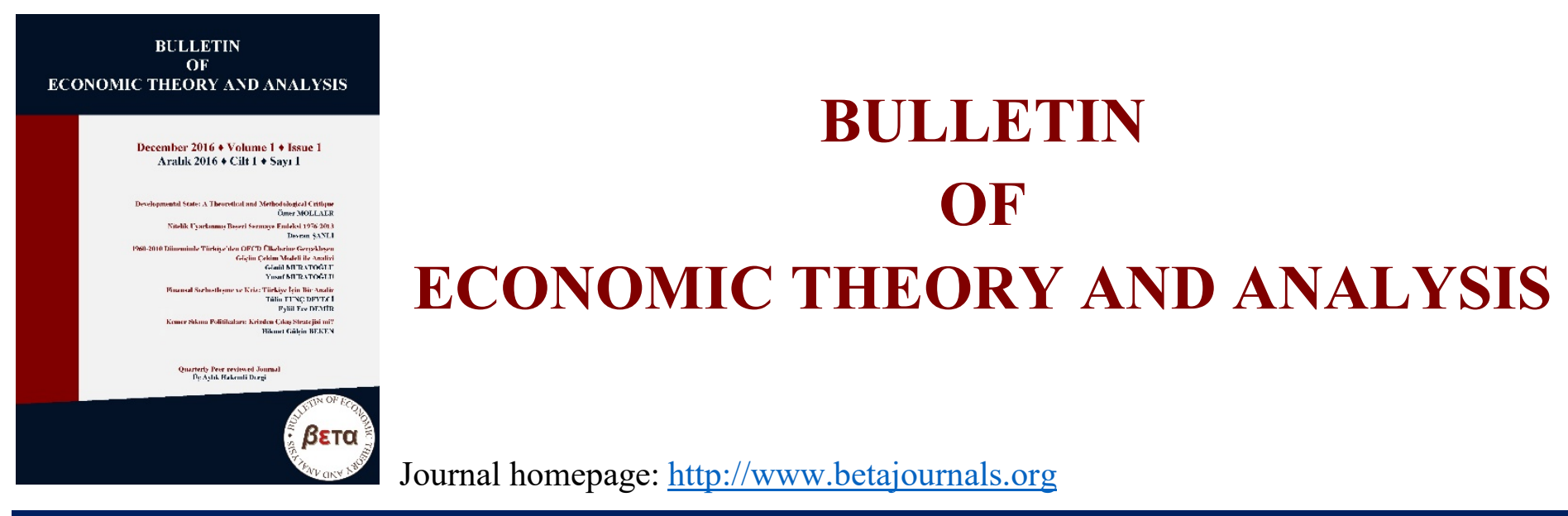

\title{
The Effects of the IMF's Quota and Governance Reforms on Turkey
}

\section{Z. Tuğrul Göver}

To cite this article: Göver, Z., T. (2018). The Effects of the IMF's Quota and Governance Reforms on Turkey. Bulletin of Economic Theory and Analysis, 3(1), 1-34.

Received: 25 Dec 2017

Accepted: 26 Sep 2018

Published online: 30 Sep 2018

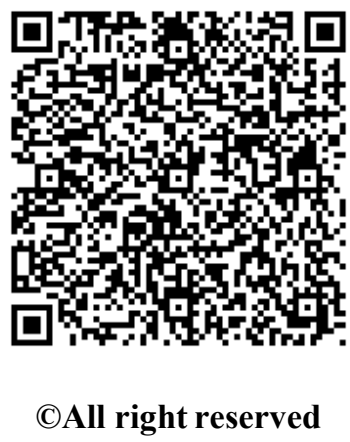




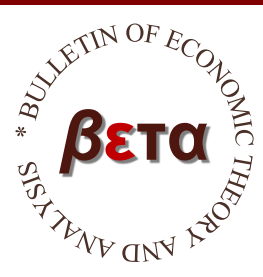

\title{
Bulletin of Economic Theory and Analysis
}

Volume III, Issue 1, pp. 1-33, 2018

http://www.betajournals.org

\section{The Effects of the IMF's Quota and Governance Reforms on Turkey}

\author{
Z. Tuğrul GÖVER ${ }^{\mathrm{a}}$ \\ ${ }^{a}$ Undersecretariat of Treasury, TURKEY
}

\begin{abstract}
Turkey became a member of the IMF in 1947 and has resorted to IMF sources many times since then. Turkey signed 19 Stand-By Arrangements with the IMF when faced with liquidity problems. Several studies have already provided detailed information about the history and evolution of the relationship between the IMF and Turkey. However, we have not come across studies about the reform efforts carried out by the IMF since 2006 and their effects on Turkey. The IMF reforms completed during the 2006-2016 period positively affected Turkey's voting power, the amount of potential financing it could use, and its representation at the Executive Board. Yet, the conditionality principle, which applies to all countries, remains valid for Turkey as well. Therefore, it would benefit Turkey to explore alternative ways in which it can obtain potential financing on more flexible terms than the IMF. The objectives of the study are to examine the reform efforts carried out by the IMF during the period 20062016 and their impact on Turkey and, to discuss the possibility of obtaining funds from other components of the Global Financial Safety Net for Turkey
\end{abstract}

\author{
Keywords \\ IMF, Global \\ Financial Safety Net, \\ conditionality \\ JEL Classification \\ F33, F36, F53
}

\footnotetext{
CONTACT Z. Tuğrul GÖVER, $₫$ govertugrul@yahoo.com $\risingdotseq$ Undersecretariat of Treasury, Turkey

*The views expressed in this paper are those of the author and do not necessarily represent the official views of the Undersecretariat of Treasury of Turkey.
} 


\section{Introduction}

Since 1945, the International Monetary Fund (IMF) has played a key role in the functioning of the global economy. The IMF strives to stabilize the global financial system and extends funding to a number of countries. In particular, developing and least developed countries resort to IMF resources, mainly when they face difficulties related to balance of payments. Thanks to its unique role, the IMF still remains at the center of the international monetary system and the Global Financial Safety Net (GFSN). In 2006, the IMF started a reform process at its own initiative at the IMF Board of Governors meeting in Singapore. While these efforts were in progress, the 2008-2009 Global Financial Crisis (GFC) sparked calls for new reforms from 2008 on. The Quota and Governance Reform Program adopted in 2010 has led to significant changes in the IMF. Thanks to those reforms, IMF quotas have been doubled, and the structure of the Executive Board has been considerably changed.

Despite all the reform programs, the IMF remains loyal to the principle of conditionality in its financing facilities. The conditionality principle, often involving controversial austerity measures, has sometimes made developing countries reluctant to borrow money from the IMF. For this reason, some developing economies with balance of payments problems sometimes prefer to use other components of the GFSN rather than the IMF. These include international organizations such as the Arab Monetary Fund (AMF) and the Latin American Reserve Fund (Fondo Latinoamericano de Reservas, FLAR). Among the layers of the GFSN, bilateral swap agreements have also come to the forefront with the 2008-2009 GFC.

Turkey became a member of the IMF in 1947 and has resorted to IMF sources many times since then. Turkey signed 19 Stand-By Arrangements with the IMF when faced with liquidity problems. Several studies have already provided detailed information about the history and evolution of the relationship between the IMF and Turkey (Erdinc, 2007; Arpac \& Bird, 2009; Arconian, 2013; Demircan \& Ener, 2014). However, we have not come across studies about the reform efforts carried out by the IMF since 2006 and their effects on Turkey. The IMF reforms completed during the 2006-2016 period positively affected Turkey's voting power, the amount of potential financing it could use, and its representation at the Executive Board. Yet, the 
conditionality principle, which applies to all countries, remains valid for Turkey as well. Therefore, it would benefit Turkey to explore alternative ways in which it can obtain potential financing on more flexible terms than the IMF. The objectives of the study are 1- to examine the reform efforts carried out by the IMF during the period 2006-2016 and their impact on Turkey and 2- to discuss the possibility of obtaining funds from other components of the GFSN for Turkey.

This study is organized as follows: In the second section, we have explained the IMF's reform programs carried out between 2006 and 2016. We have examined the impact of IMF reforms on Turkey in the third section. Then, we evaluated the international financial institutions complementary to the IMF, in other words the other components of the GFSN, which were established by the developing countries in the fourth section. In the end we have suggested a few policy options to Turkey.

\section{IMF Reform Programs During the Period 2006-2016}

\subsection{The Foundations of the IMF as a Financial Institution}

\subsubsection{Governance}

Board of Governors: It is the IMF's highest decision-making body. Among others, the most significant powers of the Board of Governors include the approval and cancellation of membership to the IMF, the allocation of quotas to the members, and the amendment of the Articles of Agreement. Each member country is represented by a governor (usually the minister of economy or finance) and an alternate governor (usually the governor of the central bank) who holds the authority to vote instead of the governor in his or her absence (Mountford, 2009).

Executive Board: The Executive Board is responsible for the administration of the IMF's daily operations and is a policy-making body. The Executive Board makes assessments on global and regional economic developments as well as developments in specific member states and also approves arrangements to extend financing facilities. As a result of the governance reforms that started in 2010, all 24 members of the board have to be elected by the constituencies. Eight 
members are elected from the single-country constituencies while the remaining sixteen members from the multi-country constituencies. The IMF reviews the number of the executive directors every eight years. The voting power assigned to the constituencies differs according to the power of the individual members included in the constituencies (Mountford, 2009; IMF, 2016b).

Managing Director: The managing director is the chairperson elected by the Executive Board. However, the director does not have a right to vote in the Executive Board. The managing director carries out the administrative work assigned by the Executive Board. He or she is also responsible for the work done by the technical staff working at the IMF and for communicating the proposed policies to the Executive Board. Traditionally, the IMF chief must be a citizen of a Western European country. However, the US' opinion is also highly important in the election of the managing director (Mountford, 2009; Peretz, 2009).

\subsubsection{IMF Quotas}

The quotas are denominated in Special Drawing Rights (SDR) for all financial transactions carried out by the IMF. The SDR, which is an international reserve asset, was created in 1969 to support the then-used fixed exchange rate system. At the outset, the value of the SDR was set at 0.888671 grams of standard gold (at that time, the equivalent of USD 1.00 in terms of gold). After the collapse of the Bretton Woods system in 1973, it was recalculated as a currency basket in major currencies of advanced economies. The Executive Board decided to add the Chinese currency renminbi to the currency basket, which sets the value of the SDR, in November 2015. Since October 2016, the weights of the currencies in SDR are as follows: US dollar $41.73 \%$, euro 30.93\%, renminbi 10.92\%, Japanese yen 8.33\% and British pound sterling 8.09\% (IMF, 2017a; Keeney, 2017).

The IMF allocates a quota to each member country, denominated in SDR, that is calculated according to a quota formula. The quota of a member is taken as the basis for all financial transactions made between the IMF and the member countries. Three functions attributed to the quotas are as follows. 
1-Subscriptions: The maximum capital contribution of a member country is set according to its quota size. Member countries pay $25 \%$ of their quota to the IMF in SDR or widely used currencies such as US dollar, euro, and Japanese yen and 75\% in their local currencies. The subscription payments constitute the main source for the credits extended by the IMF.

2-Voting power: The quota of a member also directly affects its voting power. A member's total number of votes is the sum of the number of basic votes and the number of votes dependent on its quota size. The number of basic votes allocated to the members has been increased as part of the reform efforts started in 2008. The relevant amendment to the Articles of Agreement introduced that $5.502 \%$ of the total votes would be equally distributed among the member countries. In this way, the weight of the basic votes in the total votes is fixed, no matter how the total size of the quotas would change in the future. Yet, the major part of a member's voting power usually comes from the quota-dependent part. A member is entitled to one vote for every SDR 100,000 in its allocated quota at the IMF. Thus, the larger the quota, the higher the member's voting power would be (IMF, 2011; IMF 2017b).

3-Access to IMF financing facilities: In principle, the upper limit of the funding that a member can obtain from the IMF is based on the quota allocated to that country. However, there have been a number of cases in which IMF provided such amounts of funds to some countries independent of their quota sizes for the sake of the stability of the global financial system (Copelovitch, 2010).

The Board of Governors reviews the quotas at regular intervals, usually every five years or when the Executive Board deems it necessary. To change the IMF quotas, the formal approval of three-fifths of the total number of members, which also hold at least $85 \%$ of the total voting power, is required. Under the $14^{\text {th }}$ General Quota Review, completed in 2016, the total amount of the IMF quotas has been raised to approximately SDR 477 billion (IMF, 2017b). 


\subsection{The IMF's Quota and Governance Reforms between 2006 and 2016}

In this section, we explain the 2008 and 2010 reform programs put into practice by the IMF. These sets of reforms have directly affected Turkey's position in the IMF. Since the 2009 reform program, which has dealt with the lending tools offered by the IMF, has not affected Turkey directly, we will not cover it in this study.

\subsubsection{Reform Program}

The decisions taken regarding quotas and governance at the annual meeting of the IMF Board of Governors in Singapore in 2006 lie at the heart of the 2008 reform package. As of 2006, the IMF considered that the distribution of quotas and voting power did not sufficiently reflect the relative weights of IMF members in the world economy. For this reason, the Board of Governors approved the quota and governance reforms recommended by the Executive Board at the annual meeting in Singapore in 2006. The reforms aimed at reflecting the changes in global economy in a better way in terms of quota distribution and strengthening the representation of low-income countries at the IMF. These reforms were scheduled to be completed before the IMF Board of Governors' annual meeting in 2008. The main components of the reform program are presented below (IMF, 2006a; IMF, 2006b; IMF, 2007).

- ad hoc increases in quotas allocated to China, South Korea, Mexico and Turkey, which are deemed to be the most under-represented countries at the IMF in terms of their relative weights in the global economy;

- $\quad$ agreement on a new and simple quota formula until the 2007 annual meeting of the IMF Board of Governors;

- $\quad$ as the quotas would be re-calculated according to the new formula, another round of ad hoc quota increases would be necessary;

- the Articles of Agreement would be amended to at least double the number of basic votes allocated to each member. Thus, the voting power of low-income countries would be protected; and 
creation of a second alternate executive director position, in such constituencies in which a large number of countries are included, through an amendment to the Articles of Agreement.

Ad hoc quota increases were made for four countries in line with the reform decisions taken in 2006 (see Table 1).

Table 1

The ad hoc quota increases recommended in Singapore 2006 and the corresponding voting powers

\begin{tabular}{|l|r|r|r|r|}
\hline \multirow{2}{*}{} & \multicolumn{2}{|c|}{ Pre-Singapore 2006 } & \multicolumn{2}{c|}{ Recommended in Singapore } \\
\cline { 2 - 5 } & $\begin{array}{c}\text { Quota } \\
\text { (SDR million) }\end{array}$ & $\begin{array}{c}\text { Voting } \\
\text { power (\%) }\end{array}$ & $\begin{array}{c}\text { New quota } \\
\text { (SDR million) }\end{array}$ & $\begin{array}{c}\text { New voting } \\
\text { power (\%) }\end{array}$ \\
\hline China & $6,369.2$ & 2.93 & $8,090.1$ & 3.65 \\
\hline S. Korea & $1,633.6$ & 1.20 & $2,927.3$ & 1.43 \\
\hline Mexico & $2,585.8$ & 0.76 & $3,152.8$ & 1.33 \\
\hline Turkey & 964.0 & 0.45 & $1,191.3$ & 0.55 \\
\hline
\end{tabular}

Source: IMF, 2006a; Skala, Thimann, \& Wölfinger, 2007.

Furthermore, the quota formula has been simplified, and the complex quota calculation method, which involved five formulae, was replaced with a single quota formula in 2008 (Skala, Thimann, \& Wölfinger, 2007; IMF, 2008a). On the other hand, some of the reform resolutions adopted in 2006 were transferred to the 2008 reform program. The components of the reform package proposed by the Executive Board in March 2008 and adopted at the IMF Board of Governors meeting in April 2008 are as follows (IMF, 2008a; IMF, 2008b; IMF, 2008c; IMF, 2011).

- Introduction of the new quota formula: As we have mentioned, the complex quota calculation method with five formulae used before 2008 has been eliminated. The new quota formula was introduced in 2008 and included four variables with different weights. National income has $50 \%$, the openness variable has $30 \%$, the economic variability indicator has $15 \%$ and the international reserve variable has $5 \%$ weight in the quota calculation. ${ }^{1}$ Additionally, a

\footnotetext{
${ }^{1}$ The national income variable in the formula is a three-year average of GDP (a blend GDP indicator calculated through GDP based on the current exchange rates with $60 \%$ weight and GDP based on purchasing power parity exchange rates with $40 \%$ weight), the openness variable is the five-year average of the ratio of trade volume to GDP, the variability indicator is the standard deviation of current transfers and net capital flows over the last 13
} 
compression factor $(0.95)$ is included in the formula to reduce dispersion across countries in terms of quota size.

- $\quad$ Ad hoc quota increases for 54 countries that are entitled to a stronger representation according to the new quota formula: Ad hoc changes have been estimated to increase the quotas of 54 countries with gains ranging from $12 \%$ to $106 \%$. The sum of the increase in quotas has been expected to amount to SDR 20.8 billion (USD 32.7 billion) in absolute terms, and led to a rise of 4.9 percentage points in the total quota share of those 54 members. Although some developed countries such as Germany, Italy, Japan and the United States have been entitled to larger quotas according to the new formula, they have waived their rights to better serve the purposes of the reform package. A second round of quota increases of at least $15 \%$ has been envisaged for four countries (i.e., China, S. Korea, Mexico and Turkey), the quotas of which have been increased once already, following the 2006 resolutions. The countries that would receive the largest increases in voting power as a result of the reforms are Brazil, China, India, South Korea and Mexico.

- $\quad$ Tripling the number of basic votes and boosting the representation of low-income countries: Due to the quota increases completed since 1945, the share of basic votes in total votes has fallen to a level as low as $2.1 \%$. This, in turn, especially negatively affected the voting power of low-income countries. The new arrangement regarding basic votes is expected to triple the number of basic votes by the amendment to the Articles of Agreement. This increase in the basic votes is the first one since the inception of the IMF. The amendment to the agreement has been expected to ensure that the share of the basic votes in the total votes was fixed at $5.502 \%$. Therefore, future quota increases would not change the share of basic votes in total voting power. Basic votes will be equally distributed among member countries.

- $\quad$ Creation of the new alternate executive director positions for the constituencies in which a large number of countries are represented: As a result of the amendment to the Articles of Agreement under the reform program, a second alternate executive director position has been 
established for constituencies with at least 19 countries. Accordingly, the second alternate executive director positions were planned to be established for the two constituencies in which African countries are represented. This change was expected to ease the burden of heavy workload in those constituencies. However, during the approval process of the 2008 reforms, the IMF Board of Governors decided that the second alternate executive director positions could be created for the constituencies in which at least seven countries were represented.

For these reforms to take effect, a few conditions should be met. For example, the quota increases proposed under the 2008 reform program have been tied to changes to be made in the Articles of Agreement. In addition, the countries that would benefit from the quota increases need to officially consent and pay the required subscriptions. The amendments to the Articles of Agreement enter into force with the approval of three-fifths of the member countries, which also held $85 \%$ of the total voting power. The 2008 reforms came into effect in March 2011 with the approval of 117 countries with more than $85 \%$ of the voting power (IMF, 2011).

In addition to the 2008 Quota and Governance Reforms, the IMF started to reform its lending instruments in 2009 as a consequence of the GFC. This reform aimed at reviewing the financing facilities provided by the IMF. We regard that the reform on lending instruments lies out of the scope of this study and it has not directly affected Turkey since it finalized the last Stand-By Arrangement in 2008 (IMF, 2009).

\subsubsection{Reform Program}

While the approval process of the 2008 reforms was in progress, the IMF has drafted a new reform program in 2010. Thus, the 2010 reform package, also known as the Quota and Governance Reform, can be regarded as a sequel to the 2008 reforms. In November 2010, the IMF Executive Board informed the Board of Governors regarding the reforms it proposed. At the December 2010 meeting of the IMF Board of Governors, this reform program was accepted by 95\% majority. The main elements of the 2010 reform program are presented below (IMF, 2010a; IMF, 2010b; IMF, 2011; Lesage, Debaere, Dierckx, \& Vermeiren, 2013). 
- doubling the IMF's overall quota size under the $14^{\text {th }}$ General Quota Review;

- comprehensive review of the quota formula;

- elimination of the appointed executive directors category and introduction of the allelected IMF Executive Board; and

- reduction in representation of the advanced European countries at the Executive Board.

The first two components mentioned above are related to quotas, while the last two are related to governance of the IMF. At the outset, the 2010 reforms have been scheduled to be completed by the annual meeting of IMF Board of Governors in October 2012. We explain the 2010 reforms in detail in two separate sections below.

\subsubsection{Quota-related Reforms}

\subsection{Doubling the IMF's overall quota size under the $14^{\text {th }}$ General Quota Review.}

The IMF's quota size has decayed over time compared to the global economic developments since the last general quota increase in 1998. Thus, the IMF, that sticked with the principle to keep the quotas as the main source of its finances, acknowledged that an overall quota increase has become a necessity by 2010 . With the 2010 reform program, it was agreed that the total quota would be increased by $100 \%$, from SDR 238.4 billion to SDR 476.8 billion (IMF, 2010a; IMF, 2011).

The conditions that had to be met for the quota increases to take effect are 1- the rises in quotas had to be approved by countries representing at least $70 \%$ of the total quotas as of November 5, 2010 and 2- the amendment to the Articles of Agreement regarding the structure of the Executive Board should come into force. This amendment could be effective once approved by at least $3 / 5$ of the total number of members (i.e., 113 countries) that also represented at least $85 \%$ of the total voting power. This has meant that the implementation of the overall quota increase has been tied to the amendment to the Articles of Agreement (IMF, 2012a). 
The first condition for the implementation of the quota reform was fulfilled by September 2012 (IMF, 2012b). 124 members that held 73.4\% of the total voting power approved the overall quota increase in 2012. As regards the second condition, the approval procedure was complicated to some extent because it consisted of two parts. As of end-2012, 129 countries, well above the required 113, accepted the amendment to the Articles of Agreement. Hence, the first part of the second condition has been fulfilled quite quickly. However, the second part, that required the consent of at least $85 \%$ of the voting power, could not be met for about three years (see Table 2) because the US did not accept the amendments to the Articles of Agreement until December 2015. Holding more than $15 \%$ of the votes, the US exercised its veto power. Consequently, quota increases have not become effective until January 2016 (IMF, 2016b).

Table 2

Approval status of the 2010 Quota and Governance Reform

\begin{tabular}{|l|r|r|r|r|}
\hline & \multicolumn{2}{|c|}{ Quota Reform } & \multicolumn{2}{c|}{ Governance Reform } \\
\hline & $\begin{array}{c}\text { Number of } \\
\text { Countries }\end{array}$ & \multicolumn{1}{|c|}{$\begin{array}{c}\text { Voting Power } \\
(>=70 \%)\end{array}$} & $\begin{array}{c}\text { Number of } \\
\text { Countries } \\
(>=113)\end{array}$ & $\begin{array}{c}\text { Voting Power } \\
(>=85 \%)\end{array}$ \\
\hline Dec. 2011 & 53 & 35.9 & 38 & 30.0 \\
\hline Sept. 2012 & 124 & 73.4 & 105 & 70.2 \\
\hline Dec. 2012 & 145 & 77.1 & 129 & 71.3 \\
\hline Apr. 2013 & 148 & 77.4 & 146.1 \\
\hline Jan. 2014 & 157 & 78.6 & 146 & 77.1 \\
\hline Jan. 2015 & 163 & 99.8 & 149 & 94.0 \\
\hline Jan. 2016 & 183 & & & 76.1 \\
\hline
\end{tabular}

Source: IMF

Note: Shaded cells represent the dates that the relevant conditions have been met.

To see the impact of quota reforms carried out between 2006 and 2016, we compare the quota distribution valid at the annual meeting in Singapore in 2006, with the new distribution in 2016. As of 2006, the US was at the top in terms of quota size and voting power. The top 10 countries consisted of all G-7 members and China, Saudi Arabia and Russia. The total voting power of the top 10 countries stood around 54.5\%. Turkey with a quota of SDR 964 million had a voting power of $0.45 \%$ (see Table 3 ). 
Table 3

Top 10 IMF members and Turkey by quota size and voting power, as of end-2006 (SDR million)

\begin{tabular}{|r|l|r|r|r|r|}
\hline & Country & Quota size & $\begin{array}{l}\text { Percentage } \\
\text { share }\end{array}$ & $\begin{array}{l}\text { Voting } \\
\text { power }\end{array}$ & $\begin{array}{l}\text { Percentage } \\
\text { share }\end{array}$ \\
\hline 1 & United States & $37,149.3$ & 17.40 & 371,743 & 17.08 \\
2 & Japan & $13,312.8$ & 6.24 & 133,378 & 6.13 \\
3 & Germany & $13,008.2$ & 6.09 & 130,332 & 5.99 \\
4 & France & $10,738.5$ & 5.03 & 107,635 & 4.95 \\
5 & United Kingdom & $10,738.5$ & 5.03 & 107,635 & 4.95 \\
6 & Italy & $7,055.5$ & 3.30 & 70,805 & 3.53 \\
7 & S. Arabia & $6,985.5$ & 3.27 & 70,105 & 3.22 \\
8 & Canada & $6,369.2$ & 2.98 & 63,942 & 2.94 \\
9 & China & $6,369.2$ & 2.98 & 63,942 & 2.94 \\
10 & Russia & $5,945.4$ & 2.79 & 59,704 & 2.74 \\
\hline & Turkey & 964.0 & 0.45 & 9,890 & 0.45 \\
\hline & Other & $94,842.3$ & 44.44 & 986,234 & 45.08 \\
\hline & Total & $213,478.4$ & 100.00 & $2,175,345$ & 100.00 \\
\hline
\end{tabular}

Source: IMF annual reports.

Note: Shaded rows demonstrate the BRIC countries.

As of the end of April 2016, the US still ranks first in terms of quota size and voting power. In addition, the US retained its veto power over the changes to the IMF's Articles of Agreement since its voting power remained above 15\% after the 2010 quota reform. By 2016 a G-7 member, namely Canada, has dropped out of the top 10, while all the BRIC countries (Brazil, Russia, India and China) had places among the top 10. However, the total voting power of the BRIC countries remained at $13.65 \%$. Accordingly, BRIC countries have not been able to gain veto power in the aftermath of the 2010 reforms. As a result of the quota increases between 2006 and 2016, Turkey's quota and voting power jumped to SDR 4,658.6 million and 0.96\%, respectively (Table 4). 
Table 4

Top 10 IMF members and Turkey by quota size and voting power, as of April 2016 (SDR million)

\begin{tabular}{|r|l|r|r|r|r|}
\hline & Country & Quota size & $\begin{array}{l}\text { Percentage } \\
\text { share }\end{array}$ & $\begin{array}{l}\text { Voting } \\
\text { power }\end{array}$ & $\begin{array}{l}\text { Percentage } \\
\text { share }\end{array}$ \\
\hline 1 & United States & $82,994.2$ & 17.60 & 831,395 & 16.66 \\
2 & Japan & $30,820.5$ & 6.54 & 309,658 & 6.21 \\
3 & China & $30,482.9$ & 6.46 & 306,282 & 6.14 \\
4 & Germany & $26,634.4$ & 5.65 & 267,797 & 5.37 \\
5 & France & $20,155.1$ & 4.27 & 203,004 & 4.07 \\
6 & United Kingdom & $20,155.1$ & 4.27 & 203,004 & 4.07 \\
7 & Italy & $15,070.0$ & 3.20 & 152,153 & 3.05 \\
8 & India & $13,114.4$ & 2.78 & 132,597 & 2.66 \\
9 & Russia & $12,903.7$ & 2.74 & 130,490 & 2.61 \\
10 & Brazil & $11,042.0$ & 2.34 & 111,873 & 2.24 \\
\hline & Turkey & $4,658.6$ & 0.99 & 48,039 & 0.96 \\
\hline & Other & $203,536.6$ & 43.16 & $2,292,547$ & 45.96 \\
\hline & Total & $471,567.5$ & 100.00 & $4,988,839$ & 100.00 \\
\hline
\end{tabular}

Source: IMF annual reports.

Note: Shaded rows demonstrate the BRIC countries.

\subsection{Comprehensive review of the quota formula}

Another major element of the reform package has been the revision of the quota formula. As we have mentioned earlier throughout the study, a change in the quota formula leads to changes in quota sizes of IMF members. The Executive Board started to work on a new quota formula in March 2012. It was agreed that the new formula would be simple and transparent, compatible with the functions of the quotas, and calculated easily with available data (IMF, 2012a). By 2013, the Executive Board stated that it would be better to address this review within the scope of the $15^{\text {th }}$ General Quota Review in its report on the new quota formula. However, since the quota increases under the $14^{\text {th }}$ General Quota Review did not go into effect until 2016, the $15^{\text {th }}$ Review could not be initiated either. Thus, the IMF has been able start its work on the $15^{\text {th }}$ General Quota Review, including the revision of the quota formula, in 2016. It has been targeted to finalize the review of the formula until the annual meeting to be held in 2019 (IMF, 2013; IMF, 2016b; IMF, 2016c). 


\subsubsection{Governance-related Reforms}

2.2.2.2.1. Elimination of the appointed executive director category and introduction of the allelected IMF Executive Board.

As noted above, the Executive Board consists of 24 members and the number of the seats is reviewed every eight years. Prior to the 2010 reform program, five member states with the largest voting shares in the IMF (US, Japan, Germany, France and UK) had the right to appoint their own executive directors. As the amendments to the Articles of Agreement entered into force in January 2016, the Executive Board was entirely formed of elected members. Thus, the category of appointed executive director has been eliminated. From 2016 on, the US, Japan, Germany, France and the UK, previously represented by appointment, have technically become eligible to be included in multi-country constituencies. However, as eight members (US, Japan, Germany, France, UK, Russia, China and Saudi Arabia) remained in the single-country constituencies, they will be directly represented at the Executive Board (IMF, 2010a; Lesage, Debaere, Dierckx, \& Vermeiren, 2013; IMF, 2016b).

2.2.2.2.2. Reduction in representation of the advanced European countries at the Executive Board.

Prior to the 2010 reform program, advanced European countries had eight seats at the Executive Board. Under the 2010 reforms, it was foreseen that two seats allocated to the advanced European countries would be replaced with representatives from the developing European economies. ${ }^{2}$ This process began with the Executive Board elections in November 2012. In 2012, Belgium joined the Dutch constituency. Thus, two full-time executive director positions, previously occupied by representatives from Belgium and the Netherlands, were combined in a single constituency, and the number of executive directors from the advanced European countries was reduced by one full seat. Furthermore, a new constituency has been formed, which included the Central and Eastern European Countries (i.e., Turkey, Austria, Belarus, Czech Republic, Hungary, Slovakia, Kosovo and Slovenia). The executive director of this constituency was agreed

\footnotetext{
${ }^{2}$ If a developing country representative is to serve in one of the two terms for which the executive director is expected to work, the period that is allocated to the executive director from the developing country is assumed to be a $1 / 2$ seat at the Executive Board.
} 
to be alternately elected from Turkey, the Czech Republic or Hungary according to the 20122022 constituency agreement. On the other hand, according the agreement in Swiss constituency, the executive director position would be rotated between Switzerland and Poland. Last but not the least, three years of 16 year rotation of the executive director position in the Nordic-Baltic Constituency would be left to the developing countries in the constituency. It is estimated that 1.64 of the two full-time executive director positions has been delivered to the developing European countries as of 2017 (Malkin \& Momani, 2011; Lesage, Debaere, Dierckx, \& Vermeiren, 2013; IMF, 2013; Keeney, 2017).

To summarize, the IMF planned and implemented many reforms during the period 20062016. However, reform programs have not always been implemented in line with the formal reform resolutions. For example, the work on the new quota formula could not be finalized since 2010. In the next section, we discuss the effects of the 2008 and 2010 reform programs on Turkey.

\section{The Effects of the IMF's Quota and Governance Reforms between 2006 and 2016 on Turkey}

\subsection{The Effects of the 2008 Reform Program on Turkey}

As a result of the 2006 Singapore annual meeting and the 2008 reform program, Turkey's IMF quota and voting power increased. As we have noted in the previous section, the IMF Board of Governors granted ad hoc quota increases to China, South Korea, Mexico, and Turkey at the annual meeting in Singapore in 2006. Thanks to this decision, Turkey's quota rose from SDR 964 million to approximately SDR 1,191 million. Later on, with the 2008 reform program Turkey experienced another round of rise in its quota size and voting power. A few reasons underlied this increase. The first reason was related to the re-calculation of quota sizes according to the simplified quota formula. The new quota formula has better taken into account Turkey's relative weight in the world economy. Another factor that affected Turkey's voting power was the rise in the share of basic votes in total votes. These arrangements under the 2008 reforms came into effect in 2011. As of April 2012, Turkey's quota size and number of votes increased to approximately SDR 1,456 million and 15,295, respectively. Accordingly, Turkey's share in total 
quotas and total votes rose from $0.45 \%$ to $0.61 \%$ in April 2012, with respect to 2006 (see Table $5)$.

\subsection{The Effects of the 2010 Reform Program on Turkey}

The IMF's 2010 reform program influenced Turkey in terms of representation at the Executive Board as well as quota size and voting power. The $14^{\text {th }}$ the General Quota Review envisaged an increase in the IMF's total quota by $100 \%$. However during this revision Turkey's quota rose by around 220\%, and climbed up approximately to SDR 4,659 million. Therefore, Turkey obtained a relatively higher quota increase than the average rate. Turkey has also benefited from the 2010 reforms in terms of voting power. Turkey's number of votes has jumped from 15,295 to 48,039 thanks to the 2010 reforms. The voting power is consisted of 1,453 basic votes and 46,586 quota-based votes. Accordingly, Turkey's relative voting share increased from $0.61 \%$ to $0.96 \%$ as of 2016 compared to 2012 (see Table 5).

Table 5

Turkey's quota and voting power at the IMF (2006-2016)

\begin{tabular}{|r|r|r|r|r|r|r|}
\hline & $\begin{array}{c}\text { Turkey's } \\
\text { quota size } \\
\text { (SDR million) }\end{array}$ & $\begin{array}{c}\text { Total quota } \\
\text { (SDR million) }\end{array}$ & $\begin{array}{c}\text { Percentage } \\
\text { share (\%) }\end{array}$ & $\begin{array}{c}\text { Turkey's } \\
\text { votes }\end{array}$ & Total votes & $\begin{array}{c}\text { Percentage } \\
\text { share (\%) }\end{array}$ \\
\hline 2006 & 964.0 & $213,478.4$ & 0.45 & 9,890 & $2,175,345$ & 0.45 \\
\hline 2007 & $1,191.3$ & $216,747.8$ & 0.55 & 12,163 & $2,207,764$ & 0.55 \\
\hline 2008 & $1,191.3$ & $217,372.7$ & 0.55 & 12,163 & $2,214,976$ & 0.55 \\
\hline 2009 & $1,191.3$ & $217,372.7$ & 0.55 & 12,163 & $2,214,607$ & 0.55 \\
\hline 2010 & $1,191.3$ & $217,431.7$ & 0.55 & 12,163 & $2,214,607$ & 0.55 \\
\hline 2011 & $1,191.3$ & $237,355.7$ & 0.50 & 12,163 & $2,506,798$ & 0.49 \\
\hline 2012 & $1,455.8$ & $238,116.4$ & 0.61 & 15,295 & $2,512,807$ & 0.61 \\
\hline 2013 & $1,455.8$ & $238,118.0$ & 0.61 & 15,295 & $2,515,719$ & 0.61 \\
\hline 2014 & $1,455.8$ & $238,120.6$ & 0.61 & 15,295 & $2,515,745$ & 0.61 \\
\hline 2015 & $1,455.8$ & $238,182.7$ & 0.61 & 15,295 & $2,520,571$ & 0.61 \\
\hline 2016 & $4,658.6$ & $471,567.5$ & 0.99 & 48,039 & $4,988,839$ & 0.96 \\
\hline
\end{tabular}

Source: IMF annual reports.

Note: As of end-financial year.

Within the scope of the 2010 governance reforms, a new constituency has been created with a voting power of $3.22 \%$, in which Central and Eastern European Countries are involved. 
The countries in this group have signed a constituency agreement for the period 2012-2022. According to the eight-year rotation program (2014-2022) set by the agreement, it has been agreed that the executive director of this constituency would alternately be elected from Turkey, the Czech Republic, or Hungary. The executive director of this constituency would be elected from Turkey for two terms, namely for 2014-2016 and 2018-2020. Therefore, with the 2010 Reform Program, Turkey was entitled to take a chair at the Executive Board for the first time (Government of the Slovak Republic, 2017). With the 2008 and 2010 reform programs, the potential amount of the funds that Turkey could obtain from the IMF rose significantly. For example, the cumulative funding amount that Turkey could draw through a Stand-By Arrangement (SBA) was approximately SDR 2.9 billion as of 2006. Following the reforms, this figure increased to SDR 20.3 billion by 2017.

Although Turkey has clearly benefited from the reforms during the period 2006-2016, under the current circumstances, Turkey cannot resort to any alternative international organization in the face of a balance of payments problem other than the IMF. It is a well-known fact that, in the case of IMF financing, the IMF's conditionality principle often requires austerity policies. At this point, we suggest that Turkey can have more flexibility in its economic policies if it can create an alternative to the IMF for balance of payments financing. Thus, Turkey would be able to use external financing without being bound by the IMF's rigid conditionality principle. We analyze the potential alternative international funding sources that can be extended to developing countries in the next section.

\section{The Layers of the Global Financial Safety Net Complementary to the IMF}

Developing countries that want to use other sources of finance in addition to the IMF when balance of payments problems arise have established a number of international organizations. However, these institutions have not matured enough to provide an alternative to the IMF in terms of both operational capacity and available funds. We presume the underlying reasons for this situation are 1) the IMF still protects its dominant role as a global institution in the GFSN and 2) the other international organizations consider themselves complementary to the IMF rather than alternatives. Nonetheless, these organizations can be regarded as a good starting 
point for Turkey to seek additional policy options. In this section, we give brief information on the Arab Monetary Fund (AMF), the Latin American Reserve Fund (Fondo Latinoamericano de Reservas, FLAR), the Chiang Mai Initiative Multilateralization (CMIM) and the Contingent Reserve Arrangement (CRA) in the order of their inception dates. Finally, we analyze bilateral swap arrangements (BSA) signed between the central banks. These institutions are also referred to as layers of the GFSN (IMF, 2016d).

\subsection{Arab Monetary Fund (AMF)}

The AMF, which has currently 22 members, was created in 1976 for financing the balance of payments needs of Arab countries. The headquarters of the AMF is located in the United Arab Emirates. The AMF's highest decision-making body is the Council of Governors. Daily work is carried out by the Board of Executive Directors, which has eight members. The assets and liabilities of the fund are denominated in its own currency, the Arab accounting dinar (AAD), which is assumed to be equivalent to three SDRs. Subscriptions and AMF reserves constitute the main source of the financial facilities that member countries can obtain from the AMF. In 2013, the AMF Council of Governors decided to increase the capital of the fund from AAD 300 million to AAD 900 million. The member countries' participation process in the capital increase is still ongoing. By 2016, the available funds offered by the AMF amounted to around AAD 1.2 billion (USD 4.8 billion). The AMF's purposes for extending funds to member countries are 1) financing balance of payments difficulties and 2) supporting reforms in various sectors. The AMF offers nine financing vehicles. Recipients must commit to take fiscal policy measures or make structural reforms to benefit from most of such financing instruments. The AMF provided AAF 2.1 billion (USD 8.4 billion) of funds through 177 credit agreements to member countries from 1978 to 2016. Structural adjustment facilities, extended loans and automatic loans were first three largest categories of loans extended by the AMF over the entire period. It is important to note that there is no conditionality to use automatic loans from those facilities (AMF, 2017).

The financial resources available at the AMF are significantly lower than those of the IMF for the countries that are members of both the AMF and the IMF. AMF members had a total quota of SDR 24.8 billion (USD 35 billion) at the IMF as of 2016. The total size of the resources 
that these countries can use with Stand-By Arrangements (SBA) is cumulatively SDR 107.9 billion (USD 152 billion). This figure is much higher than the amount that is available at the AMF. As of 2016, some AMF countries have standing loan agreements with the IMF, and their total debt is SDR 3.5 billion (USD 4.9 billion). Hence, we conclude that the AMF members admitted to taking harder policy actions to draw larger loans from the IMF (IMF, 2016b; AMF, 2017).

\subsection{Latin American Reserve Fund (Fondo Latinoamericano de Reservas, FLAR)}

FLAR was established in 1989 to provide financial support to Latin American countries in the face of balance of payments problems. ${ }^{3}$ The organization has currently eight members (Venezuela, Colombia, Costa Rica, Ecuador, Peru, Bolivia, Uruguay and Paraguay). The administrative office of the FLAR is in Colombia. The subscriptions that have been collected from the member countries are used for extending loans to members. As of 2017, the total capital commitment of FLAR members is USD 3.9 billion. In 2003 and 2006, FLAR also issued bonds of USD 400 million to improve its financial capacity. The size of the financial facilities that FLAR can extend to a member is set according to its capital share. As of 2017, the total amount of resources that the FLAR can offer to its members is around USD 7 billion. Up until 2017, all members except Uruguay and Paraguay have borrowed from FLAR. The members are loyal to the terms of the loans that they have obtained. Peru and Ecuador are especially impressive examples of loyalty. Both countries have paid back their loans to FLAR even during such periods when they could not pay their other creditors. So far, the countries that used funds from FLAR have never defaulted. FLAR has committed a total of USD 13 billion in loans to its members from its inception till the end of 2016. Balance of payments loans constitute around $52 \%$ of the loan agreements, whereas liquidity loans represent $40 \%$ of the total amount. FLAR has approved the credit facilities within a month on average, and the loans have not been subject to any conditionality. These features of the loans imply that the requirements for borrowing from FLAR are quite flexible (Ocampo \& Titelman, 2012; Titelman, Vera, Carvallo, \& Perez Caldentey, 2013; Ocampo, 2015; FLAR, 2017a; FLAR, 2017b).

\footnotetext{
${ }^{3}$ The Andean Reserve Fund (FondoAndino de Reservas, FAR), which was established in 1978 for financial cooperation between Venezuela, Bolivia, Colombia, Ecuador and Peru, has been converted into FLAR.
} 
Financial sources of FLAR are relatively low compared to those the member countries can borrow from the IMF. However, we presume that those two figures are relatively closer to one another for Costa Rica, Bolivia and Paraguay. For example, Paraguay can obtain a potential loan from the IMF through an SBA of USD 1.2 billion, and it can borrow up to USD 600 million from FLAR. Therefore, FLAR, which offers financial facilities with more flexible terms, can be considered an alternative to the IMF for these countries. As of 2016, FLAR members have a total IMF quota of around SDR 9 billion (USD 12.8 billion). The total amount that these countries can obtain from the IMF through SBAs is about SDR 39.3 billion (USD 55.5 billion) cumulatively. Countries that are willing to engage in relatively large credit agreements have to apply to the IMF. For example, Colombia signed a precautionary Flexible Credit Line (FCL) agreement with the IMF for SDR 8.2 billion (USD 11.5 billion) in 2016 against global risks. Therefore, we presume that FLAR cannot be an alternative to the IMF in the current situation, but might be a good complement to it (Ocampo, 2015; IMF, 2016a; IMF, 2016b).

\subsection{Chiang Mai Initiative Multilateralization (CMIM)}

The Chiang Mai Initiative $\left(\mathrm{CMI}^{4}\right)$, which was established by China, Japan and South Korea $^{5}$ in addition to the Association of Southeast Asian Nations ${ }^{6}$ (ASEAN) in 2000, was transformed into the CMIM in 2009. The CMIM agreement went into force in 2010. The objectives of the CMIM are 1) to finance balance of payments or provide short term liquidity and 2) to support existing international financial agreements in the ASEAN +3 countries and Hong Kong. The main financing method is multilateral swap arrangements between countries that are parties to the CMIM treaty. Thus, from 2010 onward, the CMIM replaced bilateral swap arrangements (BSA) with multilateral swap agreements. A quota has been set for each country that is party to the CMIM. Under the CMIM, a member that needs liquidity will sell its local

\footnotetext{
${ }^{4}$ In the aftermath of the 1997 Asian Crisis, the CMI was created in 2000 by the Association of Southeast Asian Nations (ASEAN) members and China, Japan and South Korea to improve regional financial co-operation. It was expected that in cases of balance of payments problems, the ASEAN countries and China, Japan and South Korea would make bilateral swap arrangements (BSA). One can take the creation date of the ASEAN arrangements (ASA) back to 1977. Between 1979 and 1992, the ASEAN members made five small-scale swap arrangements. However, after the Asian Crisis, it was deemed necessary to strengthen this framework. Over time, the members started to sign BSAs within the CMI. As of 2009, CMI members had signed 16 BSAs for a total amount of USD 90 billion. The countries that signed the CMI treaty were allowed to make BSAs that amounted to $10 \%$ of their quotas without an IMF agreement. This proportion was raised to 20\% in 2005 (Henning, 2002; Kawai, 2015).

${ }^{5}$ ASEAN members plus China, Japan and South Korea are also known as ASEAN +3 .

${ }^{6}$ Brunei Darussalam, Malaysia, Indonesia, Philippines, Singapore, Thailand, Vietnam, Cambodia, Myanmar, and Laos.
} 
currency in exchange of US dollars within the limit of its predefined quota. To use a high level of its quota through a swap arrangement, a member should have a standing or a recently completed loan agreement with the IMF, which the CMIM calls as the IMF-link. The size of the funds a member could use without an IMF commitment, in other words the de-linked portion, was initially limited to $20 \%$ of the quota.

The severe effects of the 2008-2009 Global Financial Crisis (GFC) pushed the CMIM to strengthen its financial capabilities. The improvements that took effect in July 2014 are as follows. 1) the total size of the potential swap agreements, previously USD 120 billion, has been increased to USD 240 billion; 2) the de-linked portion has been raised to $30 \%$ of the quota of a CMIM member; 3) a new lending tool (CMIM precautionary line, CMIM-PL) was introduced for the prevention of crises; and 4) the maturities and availability periods of the financing facilities provided by the CMIM have been extended. After these amendments, the total funds that some CMIM members (e.g., Malaysia and Thailand) could potentially obtain from the CMIM exceeded the funds they could borrow from the IMF through SBAs. However, no member country has yet utilized the CMIM since the amendments came into force. For institutionalization purposes, the ASEAN +3 Macroeconomic Research Center (AMRO) was established in 2011, with a mission to carry out the administrative work of the CMIM. The AMRO helps the CMIM enhance its institutional and operational capacity. In 2016, the AMRO conducted a test run on the use of IMF-linked portion of its financing facilities with the support of the IMF (Kawai, 2015; AMRO, 2017a; AMRO, 2017b).

\subsection{Contingent Reserve Arrangement (CRA)}

The CRA was created in 2014 by the BRICS countries (Brazil, Russia, India, China and South Africa), and the CRA treaty went into force in 2015. We regard the CRA as different from AMF, FLAR and CMIM because the BRICS are not based on regional cooperation. The BRICS countries have agreed that the CRA would support the GFSN and play a complementary role in the existing international monetary and financial system. The CRA was established to provide financial support to potential short-term balance of payments problems. A total of USD 100 billion has been committed by the BRICS countries for the CRA, and a quota has been allocated to each member. Similarly to the CMIM, the CRA also has IMF-linked and de-linked portions. 
The financing that can be accessed without an IMF commitment (de-linked portion) is limited to $30 \%$ of the country quota, and needless to say, the IMF-linked portion under the CRA is set at $70 \%$. In case a member needed liquidity in US dollars under the CRA, it will sell its local currency to buy USD for a maximum term of one year. Depending on the financing tool, it is possible to extend the maturity twice or three times. The highest decision-making body of the CRA is the Governing Council, in which the governors of the central banks or the ministers of finance participate. The Governing Council has such authorities as granting membership to the CRA or changing the de-linked portion of the country quotas. The other component of the governance, the Standing Committee, is responsible for the daily administrative work of the CRA (BRICS, 2014; Cattaneo, Biziwick, \& Fryer, 2015; He, 2016).

The BRICS countries had a total quota of around SDR 70.6 billion (USD 100 billion) in the IMF as of 2016. The total amount that these countries can borrow with SBAs is approximately SDR 307 billion SDR (USD 433.4 billion) (IMF, 2016b). However, the BRICS countries have not asked for IMF resources for many years. On the other hand, the CRA instruments have not been utilized since 2015. Some critics have argued that the CRA cannot be utilized even if the BRICS countries needed liquidity. The potential causes of this difficulty are 1) the relatively small size of the CRA sources compared to that of the IMF, and 2) the IMF-link condition for accessing the major part of the resources. It has been emphasized that the privilege should be given to boosting the financial capabilities of the CRA to make the organization more functional. Moreover, it has been recommended that the CRA should make arrangements to develop institutional capacity and conduct surveillance activities on member countries in a similar way to the CMIM/AMRO (Cattaneo, Biziwick, \& Fryer, 2015; He, 2016).

\subsection{Bilateral Swap Arrangements (BSA)}

During and after the 2008-2009 GFC, the central banks' interest in bilateral swap arrangements has risen significantly due to the extraordinary need for liquidity worldwide. Because of the global effects of the crisis, several swap arrangements have been made between the central banks of the advanced economies. However, since the scope of this study is limited to developing countries, we will focus on the developing country-developing country and developed country-developing country BSAs in this subsection. After 2008, the US Federal Reserve (FED) 
and the People's Bank of China (PBOC) came to the forefront as major liquidity suppliers through BSAs. However, we observe that the two central banks basically have different motivations regarding the swap arrangements.

The main motive of the US FED has been to provide liquidity to global financial markets through BSAs. In October 2008, the US FED announced that it had signed four swap agreements with the central banks of Brazil, Mexico, South Korea and Singapore, each of which amounted to USD 30 billion. The FED, taking into account the risks that the banks with US origin were exposed to, stated that these countries were deemed systemically important (FED, 2008). The BSA with South Korea Central Bank is an interesting example because South Korea preferred to make a BSA with the US FED instead of the IMF or the then-CMI. It is important to note that the swap arrangement was made for precautionary purposes, and not due to the inadequacy of South Korea's foreign exchange reserves. ${ }^{7}$ The lack of confidence in the IMF in Southeast Asia since the 1997 Asian Crisis influenced Korea's decision to not to resort to the IMF. South Korea did not opt to use the CMI either, due to the IMF-link condition. The swap arrangement between South Korea Central Bank and the FED has been put forward as a striking example of the CMI's ineffectiveness. It was argued that this BSA was so influential that it played a partial role in the CMI's transformation into the CMIM in 2009 (Aizenman, Jinjarak, \& Park, 2010; IMF, 2016d). On the other hand, the PBOC has aimed at increasing the weight of the Chinese renminbi in global trade and international reserves through bilateral swap arrangements. Contrary to the FED, the PBOC has not attached much importance to the economic foundations of the developing economy that signed the BSA. Instead, the PBOC considers whether the counterparty had a significant share in China's export volume. As of the end of 2015, the total amount of the 33 BSAs signed by the PBOC denominated in renminbi reached about yuan 3.3 trillion (approximately USD 500 billion) (IMF, 2016d; PBOC, 2016).

There is no mechanism within the FED or the PBOC to closely monitor the macroeconomic outlook of the counterparty developing countries. Moreover, in contrast with the IMF facilities, those particular swap arrangements do not include any conditionality provisions. Therefore, there is a possibility of counterparty risk, which means that the dollar-borrowing or

\footnotetext{
${ }^{7}$ South Korean Central Bank signed swap arrangements with the Central Banks of China and Japan to boost market confidence by the end of 2008 .
} 
renminbi-borrowing country may not comply with the terms of the BSA. To counter this risk, the US FED takes account of the counterparty country's relative weight in the global trade and financial markets as well as the indicators on its economic foundations, such as its level of international reserves or domestic saving rate. We cannot infer that all developing countries would be able to sign BSAs to secure liquidity in dollars because the FED's behavior would be selective while considering whether to sign an arrangement (Aizenman, Jinjarak, \& Park, 2010).

\section{Conclusion and the Policy Options for Turkey}

The IMF decided to make a series of reforms in 2008 and 2010 to strengthen its central position in the international monetary system. The 2008-2009 Global Financial Crisis and crisisrelated liquidity needs played an important role in the adoption of the reform packages. The 2010 Quota and Governance Reform, which doubled the total IMF quotas, entered into force in 2016. The IMF raised its total quotas to SDR 477 billion, reaching a fund size that could meet global liquidity needs. In terms of quota sizes, the other components of the GFSN (i.e., AMF, FLAR, CMIM and CRA) remained at a significantly lower level than the IMF.

The IMF reform efforts during the period 2006-2016 yielded positive results to Turkey in terms of its quota size, voting power and representation. Thanks to the reform packages, Turkey will be able to borrow remarkably more IMF resources in the future. However, the conditionality principle inherent in the IMF financing may require austerity measures that Turkey may be reluctant to implement. For this reason, it is important for Turkey to explore alternative external financing sources that can be obtained on more flexible terms. Under the current circumstances, we suggest that it may be in Turkey's interest to consider the following policy options.

Firstly, given the current situation, Turkey should strive to protect its gains in the IMF and increase them whenever possible. It should also try to defend its power at the IMF Executive Board during the renewal negotiations of the constituency agreement.

Turkey can get in touch with the other components of the GFSN to expand the potential external financial resources it can access. Among the four international organizations discussed within this study, the AMF, FLAR and the CMIM do not constitute promising alternatives for Turkey since they have been established to enhance cooperation within certain regions. However, 
the CRA of the BRICS countries may be a more appropriate policy option because it is open to new members and does not have a regional character. To this end, Turkey can make accession negotiations with the BRICS countries regarding the CRA. If Turkey is granted membership, it can contribute to developing its institutional capacity and thus to reduce the weight of the IMFlink for facilitating the financial tools of the CRA.

Bilateral swap arrangements between the central banks may be another potential instrument of external finance for Turkey. As a matter of fact, a swap arrangement for yuan 10 billion/Turkish lira 3 billion between Turkey's central bank and the PBOC was signed in 2012, and renewed for yuan 12 billion/Turkish lira 5 billion in 2015 (PBOC, 2016). However, the BSA with the PBOC serves to increasing the weight of the Chinese renminbi in international markets, rather than providing potential external funds to support a developing country. On the other hand, the US Federal Reserve's swap arrangements with developing countries are considered more relevant with external financing. Still, the FED has been selective about the developing country to which this facility would be offered. The FED considers the soundness of the economic foundations of a developing country in its evaluation of signing a BSA. For this reason, Turkey should strive to keep its economy sound and stable and reduce its existing vulnerabilities to be eligible to negotiate with the FED. 


\section{References}

Aizenman, J., Jinjarak, Y., \& Park, D. (2010). International reserves and swap lines: Substitutes or complements? NBER Working Papers, No: 15804. doi: 10.3386/w15804.

Arab Monetary Fund (AMF) (2017). Annual Report 2016, Abu Dhabi.

Arconian, O. A. (2013). Turkey's graduation from the IMF. Middle East Policy, 20, 122-136.

Arpac, O., \& Bird, G. (2009). Turkey and the IMF: A case study in the political economy of policy implementation. The Review of International Organizations, 4(2), 135-157. doi: 10.1007/s11558-008-9051-4.

ASEAN +3 Macroeconomic Research Office (AMRO) (2017a). AMRO Annual Report 2016, Singapore.

ASEAN +3 Macroeconomic Research Office (AMRO) (2017b). ASEAN +3 Regional Economic Outlook 2017: ASEAN +3 Region, 20 Years after the Asian Financial Crisis, Singapore.

BRICS (2014). Treaty for the Establishment of a BRICS Contingent Reserve Arrangement. Retrieved from http://brics.itamaraty.gov.br/category-english/19-press-releases/220treaty-for-the-establishment-of-a-brics-contingent-reserve-arrangement-fortaleza-july- 15 .

Cattaneo, N., Biziwick, M., \& Fryer, D. (2015). The BRICS contingent reserve arrangement and its position in the emerging global financial architecture. South African Institute of International Affairs Policy Insights, No: 10.

Copelovitch, M. S. (2010). Master or servant? Common agency and the political economy of IMF lending. International Studies Quarterly, 54, 49-77. doi: 10.1111/j.14682478.2009.00577.x.

Cortuk, O. (2006). Turkey-IMF relationship and the financial transactions on account basis [Turkish]. Proficiency Dissertation submitted to the Central Bank of the Republic of Turkey. Retrieved from http://www.tcmb.gov.tr.

Demircan, E., \& Ener, M. (2014). IMF's effect on the stabilization programs implemented in developing countries and Turkey [Turkish]. Journal of Administrative Sciences. 1. Retrieved from http://dergipark.gov.tr/comuybd/issue/4121/54206.

Erdinc, Z. (2007). The evolution of the IMF-Turkey relations and the $19^{\text {th }}$ Stand-By Arrangement [Turkish]. Dumlupinar University Journal of Social Sciences. No: 18. Retrieved from http://birimler.dpu.edu.tr/app/views/panel/ckfinder/userfiles/17/files/DERG_/18/99-116.pdf.

Federal Reserve (FED) (2008). Press Release. Release Date: 29.10.2008. Retrieved from https://www.federalreserve.gov/newsevents/press/monetary/20081029b.htm. 
Fondo Latinoamericano de Reservas (FLAR) (2017a). Annual Report 2016, Bogota.

Fondo Latinoamericano de Reservas (FLAR) (2017b). FLAR Presentation, Bogota.

He, A. (2016). China in the international financial system: A study of the NDB and the AIIB. Centre for International Governance Innovation Papers, No: 106.

Henning, C. R., (2002). East Asian Financial Cooperation. Policy Analyses in International Economics. No: 68. Peterson Institute for International Economics, Washington.

Retrieved from https://piie.com/publications/chapters_preview/345/3iie3381.pdf.

Government of the Slovak Republic (2017). Retrieved from http://www.rokovania.sk/File.aspx/Index/Mater-Dokum-171500

International Monetary Fund (IMF) (2006a). Press Release: IMF Executive Board Recommends Quota and Related Governance Reforms. Press Release No. 06/189. Retrieved from http://www.imf.org/external/np/sec/pr/2006/pr06189.

International Monetary Fund (IMF) (2006b). Press Release: IMF Board of Governors Approves Quota and Related Governance Reforms. Press Release No. 06/205. Retrieved from http://www.imf.org/en/news/articles/2015/09/14/01/49/pr06205.

International Monetary Fund (IMF) (2007). IMF Annual Report 2007, Washington.

International Monetary Fund (IMF) (2008a). IMF Annual Report 2008, Washington.

International Monetary Fund (IMF) (2008b). Press Release: IMF Board Recommends Reforms to Overhaul Quota and Voice. Press Release No. 08/64. Retrieved from http://www.imf.org/external/np/sec/pr/2008/pr0864.

International Monetary Fund (IMF) (2008c). Press Release: IMF Board of Governors Adopts Quota and Voice Reforms by Large Margin. Press Release No. 08/93. Retrieved from http://www.imf.org/en/news/articles/2015/09/14/01/49/pr0893.

International Monetary Fund (IMF) (2009). IMF Annual Report 2009, Washington.

International Monetary Fund (IMF) (2010a). Press Release: IMF Executive Board Approves Major Overhaul of Quotas and Governance. Press Release No. 10/418. Retrieved from http://www.imf.org/en/news/articles/2015/09/14/01/49/pr10418.

International Monetary Fund (IMF) (2010b). Press Release: IMF Board of Governors Approves Major Quota and Governance Reforms. Press Release No. 10/477. Retrieved from http://www.imf.org/en/news/articles/2015/09/14/01/49/pr10477. 
International Monetary Fund (IMF) (2011). IMF Annual Report 2011, Washington.

International Monetary Fund (IMF) (2012a). IMF Annual Report 2012, Washington.

International Monetary Fund (IMF) (2012b). Press Release: IMF Executive Board Reviews Progress Toward Implementation of the 2010 Quota and Governance Reform. Press Release No. 12/309.

Retrieved from http://www.imf.org/en/news/articles/2015/09/14/01/49/pr12309.

International Monetary Fund (IMF) (2013). IMF Annual Report 2013, Washington.

International Monetary Fund (IMF) (2015). International Financial Statistics CD-ROM, March 2015 .

International Monetary Fund (IMF) (2016a). Press Release: IMF Executive Board Approves New Two-Year US\$11.5 Billion Flexible Credit Line Arrangement for Colombia. Press Release No. 16/279.

Retrieved from https://www.imf.org/en/News/Articles/2015/09/14/01/49/pr16279.

International Monetary Fund (IMF) (2016b). IMF Annual Report 2016, Washington.

International Monetary Fund (IMF) (2016c). Press Release: IMF Executive Board Reports to the Board of Governors on the Fifteenth General Review of Quotas. Press Release No. 16/489. Retrieved from http://www.imf.org/en/news/articles/2016/11/04/pr16489-imfexecutive-board-reports-to-the-board-of-governors-on-the-fifteenth.

International Monetary Fund (IMF) (2016d). Adequacy of the Global Financial Safety Net, Washington.

International Monetary Fund (IMF) (2017a). IMF Factsheet: Special Drawing Right. Retrieved from http://www.imf.org/external/np/exr/facts/sdr.htm.

International Monetary Fund (IMF) (2017b). IMF Factsheet: IMF Quotas. Retrieved from http://www.imf.org/external/np/exr/facts/quotas.htm.

Istemi, E. (1985). IMF: Its creation, evolution and the relations with Turkey [Turkish] (unpublished Doctoral Dissertation). Gazi University.

Kawai, M. (2015). From the chiang mai initiative to an Asian Monetary Fund. Asian Development Bank Institute Working Paper Series, No: 527. doi: 10.2139/ssrn.2620193.

Keeney, M. J. (2017). The policy framework of the International Monetary Fund: An overview of recent developments. Quarterly Bulletin Articles No.01, Central Bank of Ireland, 92-102.

Retrieved from http://EconPapers.repec.org/RePEc:cbi:qtbart:y:2017:m:01:p:92-102. 
Lesage, D., Debaere, P., Dierckx, S. \& Vermeiren, M. (2013). IMF reform after the crisis. International Politics, 1-26. doi:10.1057/ip.2013.17

Malkin, A., \& Momani, B. (2011). Emerging powers and IMF reform: Where multipolarity in the World Economy is leading the fund? St. Anthony's International Review, 7(1), 61-78.

Mountford, A. (2009). Governance of the International Monetary Fund. In R. Lamdany \& L. Martinez-Diaz (Eds), Studies of IMF Governance: A Compendium (pp. 15-42). Washington: IMF Publications.

Ocampo, J. A. (2015). FLAR and its role in the regional and international financial architecture. In G. Perry (Ed), Building Latin American Reserve Fund: 35 Years of FLAR (pp. 155176). Bogota: Panamericana Formas e Impresos S.A.

Ocampo, J. A., \& Titelman, D. (2012). Regional monetary cooperation in Latin America. Asian Development Bank Institute Working Paper Series, No: 373. doi: 10.2139/ssrn.2128437.

People's Bank of China (PBOC) (2016). Annual Report 2015, Beijing.

Peretz, D. (2009). The Process for Selecting and Appointing the Managing Director and First Deputy Managing Director of the IMF. In R. Lamdany \& L. Martinez-Diaz (Eds), Studies of IMF Governance: A Compendium (pp. 276-289). Washington: IMF Publications.

Skala, M., Thimann, C., \& Wölfinger, R. (2007). The search for Columbus' egg: Finding a new formula to determine quotas at the IMF. European Central Bank, Occasional Paper Series No: 70 .

Titelman, D., Vera, C., Carvallo, P., Perez Caldentey, E. (2013). A regional reserve fund for Latin America. ECLAC, Financing for Development Series, No: 244 . doi: http://dx.doi.org/10.18356/46646779-en. 
ANNEX - 1

\section{A Brief History of Turkey-IMF Relationship}

Turkey became a member of IMF in 1947. As of the end of 2016, Turkey's quota is SDR 4,658.6 million and the voting power is about $0.96 \%$. Out of the total quota assigned to Turkey, the reserve tranche position is SDR 112.8 million and SDR allocation is SDR 4,545.8 million (IMF, 2016b).

Turkey utilized approximately SDR 33,821 million in total from the IMF resources between 1961 and $2008^{8}$. Turkey borrowed SDR 27,033 million through the Stand-By Arrangements (SBA), whereas it drew SDR 5,784 million from the Supplemental Reserve Facility (SRF). The remaining part of the funds that the IMF disbursed consisted of the Extended Fund Facility (EFF), the Compensatory Financing Facility (CFF), Oil Facility (OF) and the Emergency Assistance (Istemi, 1985; Cortuk, 2006; IMF, 2015) (see Table 6).

During the period 1961-2016, Turkey made SDR 33,632 million repayments to the IMF. A very large portion (SDR 29,808 million) of such payments was remitted during the period 2002-2013, following the large drawdowns between 2000 and 2002. The difference between the resources and the repayments emanated from the resources that Turkey obtained prior to 1961. Turkey completed the repayments to the IMF in 2013. As of the end of 2016, Turkey has no payment obligation to the IMF.

\footnotetext{
${ }^{8}$ According to the IMF-International Financial Statistics Turkey used IMF resources in 1953, 1957 and 1958. However, we could not find the details regarding the nature of those facilities.
} 
Table 6

The breakdown of the financial resources that Turkey obtained from the IMF by financial facilities, 1961-2008 (SDR million)

\begin{tabular}{|c|c|c|c|c|c|c|c|c|}
\hline & $\begin{array}{l}\text { No. of } \\
\text { Stand-By }\end{array}$ & SBA & SRF & $\mathrm{EFF}$ & $\mathrm{CFF}$ & OF & $\begin{array}{l}\text { Emergency } \\
\text { Assistance }\end{array}$ & $\begin{array}{c}\text { Total } \\
\text { disbursement }\end{array}$ \\
\hline 1961 & 1 & 16.00 & - & - & - & - & - & 16.00 \\
\hline 1962 & 2 & 15.00 & - & - & - & - & - & 15.00 \\
\hline 1963 & 3 & 21.50 & - & - & - & - & - & 21.50 \\
\hline 1964 & 4 & 19.00 & - & - & - & - & - & 19.00 \\
\hline 1966 & 6 & 21.50 & - & - & - & - & - & 21.50 \\
\hline 1967 & 7 & 27.00 & - & - & - & - & - & 27.00 \\
\hline 1968 & 8 & 27.00 & - & - & - & - & - & 27.00 \\
\hline 1969 & 9 & 10.00 & - & - & - & - & - & 10.00 \\
\hline 1970 & 10 & 75.00 & - & - & - & - & - & 75.00 \\
\hline 1971 & 10 & 15.00 & - & - & - & - & - & 15.00 \\
\hline 1975 & - & - & - & - & 37.75 & 169.82 & - & 207.57 \\
\hline 1976 & - & - & - & - & 37.50 & 91.74 & - & 129.24 \\
\hline 1978 & 11 & 90.00 & - & - & 74.50 & - & - & 164.50 \\
\hline 1979 & 12 & 230.00 & - & - & - & - & - & 230.00 \\
\hline 1980 & 13 & 260.00 & - & 160.00 & 71.63 & - & - & 491.63 \\
\hline 1981 & 13 & 400.00 & - & - & - & - & - & 400.00 \\
\hline 1982 & 13 & 300.00 & - & - & - & - & - & 300.00 \\
\hline 1983 & 13 and 14 & 346.25 & - & - & - & - & - & 346.25 \\
\hline 1984 & 15 & 168.75 & - & - & - & - & - & 168.75 \\
\hline 1994 & 16 & 235.50 & - & - & - & - & - & 235.50 \\
\hline 1995 & 16 & 225.00 & - & - & - & - & - & 225.00 \\
\hline 1999 & 17 & 221.72 & - & - & - & - & 361.50 & 583.22 \\
\hline 2000 & 17 & $2,622.08$ & - & - & - & - & - & $2,622.08$ \\
\hline 2001 & 17 & $3,111.16$ & $5,784.00$ & - & - & - & - & $8,895.16$ \\
\hline 2002 & 18 & $9,929.20$ & - & - & - & - & - & $9,929.20$ \\
\hline 2003 & 18 & $1,191.00$ & - & - & - & - & - & $1,191.00$ \\
\hline 2004 & 18 & 793.80 & - & - & - & - & - & 793.80 \\
\hline 2005 & 19 & $1,665.51$ & - & - & - & - & - & $1,665.51$ \\
\hline 2006 & 19 & $1,998.61$ & - & - & - & - & - & $1,998.61$ \\
\hline 2007 & 19 & 749.48 & - & - & - & - & - & 749.48 \\
\hline \multirow[t]{2}{*}{2008} & 19 & $2,248.44$ & - & - & - & - & - & $2,248.44$ \\
\hline & Total & $27,033.50$ & $5,784.00$ & 160.00 & 221.38 & 261.56 & 361.50 & $33,821.94$ \\
\hline
\end{tabular}

Source: Istemi (1985), Cortuk (2006), IMF. 
According to the IMF's 2008 annual report, the upper limit of resource utilization through a Stand-By Arrangement or an Extended Fund Facility is limited to $100 \%$ and $300 \%$ of the country quota annually and cumulatively, respectively (IMF, 2008a). However, over the periods 19801984 and 2000-2007, Turkey obtained financial resources in excess of $300 \%$ of its quota. Between 2001 and 2005, the resource utilization/quota ratio exceeded 1,000\%. Therefore, in some cases the IMF considers the country quota only as an indicator, and the quota sizeborrowing capacity relationship is not always binding.

Turkey and the IMF signed 19 Stand-By Arrangements throughout 1961-2008. Out of the 19 SBAs, only seven have been finalized according to the terms of the loan agreement and, therefore fully utilized. Turkey signed the first Stand-By Arrangement in the end of 1961 and, the $19^{\text {th }}$ arrangement in May 2005. The IMF disbursed the last tranch of the $19^{\text {th }}$ SBA in 2008. The total amount of the loans under the SBAs that Turkey had expected to draw was SDR 31,923 million. However, Turkey actually utilized a total of SDR 27,033 million under the SBAs (see Table 7).

Table 7

The Stand-By Arrangements signed between the IMF and Turkey, 1961-2008 (SDR million)

\begin{tabular}{|c|c|c|c|c|c|c|}
\hline & $\begin{array}{c}\text { Date of } \\
\text { Stand-By } \\
\text { Arrangement }\end{array}$ & $\begin{array}{c}\text { Duration } \\
\text { (No. of } \\
\text { Months) }\end{array}$ & $\begin{array}{l}\text { Amount of the } \\
\text { Facility } \\
\text { (SDR million) }\end{array}$ & $\begin{array}{c}\text { Disbursed } \\
\text { Amount } \\
\text { (SDR million) }\end{array}$ & $\begin{array}{l}\text { Undisbursed } \\
\text { Amount (SDR } \\
\text { million) }\end{array}$ & Status \\
\hline 1 & 01.01 .1961 & 12 & 37.50 & 16.00 & 21.50 & Partial utilization \\
\hline 2 & 30.03 .1962 & 9 & 31.00 & 15.00 & 16.00 & Partial utilization \\
\hline 3 & 15.02 .1963 & 11 & 21.50 & 21.50 & - & Completed \\
\hline 4 & 15.02 .1964 & 11 & 21.50 & 19.00 & 2.50 & Cancelled \\
\hline 5 & 01.02 .1965 & 12 & 21,50 & 0.00 & 21.50 & Partial utilization \\
\hline 6 & 01.02 .1966 & 12 & 21.50 & 21.50 & - & Completed \\
\hline 7 & 15.02 .1967 & 11 & 27.00 & 27.00 & - & Completed \\
\hline 8 & 01.04 .1968 & 9 & 27.00 & 27.00 & - & Completed \\
\hline 9 & 01.07 .1969 & 12 & 27.00 & 10.00 & 17.00 & Cancelled \\
\hline 10 & 17.08 .1970 & 12 & 90.00 & 90.00 & - & Completed \\
\hline 11 & 24.04 .1978 & 24 & 300.00 & 90.00 & 210.00 & Cancelled \\
\hline 12 & 19.07 .1979 & 12 & 250.00 & 230.00 & 20.00 & Cancelled \\
\hline 13 & 18.06 .1980 & 36 & $1,250.00$ & $1,250.00$ & - & Completed \\
\hline 14 & 24.06 .1983 & 12 & 225.00 & 56.25 & 168.75 & Cancelled \\
\hline 15 & 04.04 .1984 & 12 & 225.00 & 168.75 & 56.25 & Cancelled \\
\hline 16 & 08.07 .1994 & 14 & 610.50 & 460.50 & 150.00 & Cancelled \\
\hline 17 & 22.12 .1999 & 36 & $9,254.00$ & $5,954.96$ & $3,299.04$ & Cancelled \\
\hline 18 & 04.02 .2002 & 36 & $12,821.20$ & $11,914.00$ & 907.20 & Partial utilization \\
\hline 19 & 11.05 .2005 & 36 & $6,662.04$ & $6,662.04$ & - & Completed \\
\hline & & Total & $31,923.24$ & $27,033.50$ & $4,889.74$ & \\
\hline
\end{tabular}

Source: Istemi (1985), Cortuk (2006), IMF. 
We explain the financial tools that Turkey used in the past, but not currently offered by the IMF, in the following part.

\section{Supplemental Reserve Facility}

The IMF began to offer the Supplemental Reserve Facility (SRF) when the Asian crisis emerged in 1997. The Fund aimed at providing short-term financing for the balance of payments problems that arose due to the crisis in the IMF members. It was an option only available when a member had an active SBA or EFF, and when policies were in place to establish market confidence. The SRF was abolished in 2009 during the revision of lending instruments. Turkey utilized the Supplemental Reserve Facility during the 2001 crisis (Cortuk, 2006; IMF, 2009).

\section{Compensatory Financing Facility}

The Compensatory Financing Facility (CFF) was put into practice in 1963. It was used to provide medium-term financing to the member countries that had trade deficits which emanated from the deterioration in terms of trade. The IMF extended the CFF only if an exogenous shock deteriorated the terms of trade. The IMF terminated offering the CFF following the reform on lending tools. Turkey used the Compensatory Financing Facility due to the oil shocks that occurred between 1975 and 1980 (Cortuk, 2006; IMF, 2009).

\section{Oil Facility}

The Oil Facility was used to finance the member countries' balance of payments in the face of the sudden rise in oil prices in the 1970s. Turkey used the Oil Facility in 1975 and 1976. The IMF no longer offers the Oil Facility (Cortuk, 2006).

\section{Emergency Assistance}

The Emergency Assistance was a financial facility that was available to member states that suffered from internal conflicts or, natural disasters. Credits for natural disasters were available since 1962 already. Additionally, the IMF began to offer the post-conflict loans since 1995. Turkey used the Emergency Assistance in 1999 due to the Marmara earthquake. This lending instrument was converted into the rapid financing instrument (RFI) in 2011 (IMF, 2012a). 